\title{
ANALISIS KESTABILAN MODEL PERTUMBUHAN SEL KANKER DENGANTERAPI GEN ONYX P53
}

\author{
M Zulkifli Warli1 ${ }^{1}$, Syamsuddin Toaha ${ }^{2}$, Kasbawati ${ }^{3}$ \\ Universitas Hasanuddin $1,2,3$ \\ Email: zulkifliwarli94@gmail.com¹, syamsuddint@yahoo.com², kasbawati@gmail.com³
}

\begin{abstract}
Abstrak. Penelitian ini adalah Penelitian pengembangan (Research dan Development) yang bertujuan untuk menganalisis kestabilan titik kesetimbangan dari model penyebaran sel kanker dengan terapi gen dengan meninjau interaksi antara virus (V) dengan Sel imun (C), virus dengan sel tumor(T) dan sel imun dengan sel tumor menggunakan ONYX P53. Langkah-langkahnya adalah menentukan model Terapi Gen ONYX P53 dengan meninjau model terapi gen, mencari titik keseimbangan dengan penyakit dan bebas penyakit untuk setiap titik kesetimbangan penyakit dan bebas penyakit, menentukan persamaan karakteristik dan nilai eigen matriks Jacobian. Selanjutnya, menganalisis kestabilan di sekitar titik kesetimbangan penyakit dan bebas penyakit selanjutnya menyelesaikan simulasi numerik. Dari simulasi yang diberikan diketahui bahwa dengan memberikan nilai parameter dasar menghasilkan satu titik kesetimbangan bebas penyakit yang stabil yaitu Q1 dan tidak memiliki titik kesetimbangan penyakit. Sedangkan pada parameter pembanding menghasilkan satu titik kesetimbangan bebas penyakit namun tidak stabil dan menghasilkan dua titik kesetimbangan penyakit yaitu Q2 dan Q5. Titik kesetimbangan Q2 tidak stabil sedangkan Q5 stabil.
\end{abstract}

\section{Kata Kunci: Terapi Gen, Sistem Persamaan Differensial, Titik Kesetimbangan, Analisis kestabilan.}

\begin{abstract}
This research is research and development (Research and Development) which aims to analyze the stability equilibrium point of the model of spread of cancer cells with gene therapy by examining the interaction between virus $(\mathrm{V})$ and immune cells $(\mathrm{C})$, virus with tumor cells $(\mathrm{T})$ and immune cells with tumor cells using Onyx P53. Researchers use qualitative methods to achieve the object of research. The steps are to determine the Onyx P53 Gene Therapy model by reviewing the gene therapy model, looking for disease and disease-free equilibrium points for each disease and disease-free equilibrium point, determining characteristic equations and Jacobian matrix eigenvalues. Furthermore, analyzing the stability around the disease and disease-free equilibrium points further completes the numerical simulation. From the given simulation, it is known that by providing the basic parameter values, it produces a stable disease-free equilibrium point, namely $\mathrm{Q} 1=(0,0,0,1)$ and has no disease equilibrium point. While the comparison parameter produces one disease-free equilibrium point but is unstable and produces two disease equilibrium points, namely Q2 and Q5.The equilibrium point Q2 is unstable while Q5 is stable.
\end{abstract}

Keywords: Gene Therapy, Differential Equation System, Equilibrium point, Stability Analysis.

\section{A. Pendahuluan}

Dalam upaya perawatan penderita kanker, metode perawatan yang terbaru dan sampai saat ini masih dalam tahap penelitian oleh para saintis adalah Gene Therapy (terapi gen). Pengobatan kanker kemudian mengalami perubahan yang sangat berpengaruh sebagai pemahaman tentang proses biologis yang kemudian mendasari terjadinya penyakit kanker. Salah satu terapi yang kemudian di harapkan menjadi pengobatan yang paling efektif di masa yang akan datang adalah Gene Therapy (terapi gen), sehingga dapat secara akurat mengobati kanker (Lestari, D; Sari, E. R; \& Arifah, H. 2019).

Penyakit kanker merupakan perubahan genetik manusia sehingga metode terapi gen yang menjadi salah satu jenis pengobatan terhadap kanker. Perubahan genetik dapat mengakibatkan regulasi siklus sel pada sel normal terdapat keseimbangan antara poliferasi atau perkembangbiakan sel dengan kematian sel yang diregulasi melalui siklus sel dengan cellular 
checkpoint (Lai, 2014). Metode Terapi gen pada penyakit kanker sampai saat ini masih dalam tahap penelitian, tetapi kemajuan yang sangat pesat juga telah diperoleh pada beberapa uji klinik. Walaupun banyak sekali tantangan yang harus dihadapi, namun metode Terapi Gen telah menunjukan pengobatan yang baik dan efektif bagi sejumlah penderita kanker (Lestari, 2015).

Model terapi gen untuk pengobatan kanker dibentuk berdasarkan pada model Kirschner dan Panetta dengan menghilangkan populasi ketiga. Interaksi sel efektor dan sel kanker dalam terapi gen telah di modelkan secara matematis oleh Tsygvinsev dkk (Tsygvintsev, 2013). Dalam tulisannya, Tsygvinsev dkk mengaplikasikan model matematika sederhana untuk menyelidiki bagaimana dinamika pertumbuhan sel efektor dan sel kanker dalam pengobatan terapi gen, dengan tujuan utama yaitu memprediksi kombinasi optimal dari pendekatan yang mengarah ke pembersihan kanker.

Kemudian pada pendekatan terapi gen dalam pengobatan kanker, secara umum penerapan terapi gen dilakukan dengan cara mengganti atau menginaktifkan gen yang tidak berfungsi, menambahkan gen fungsional atau menyisipkan gen ke dalam sel untuk membuat sel berfungsi normal (Arteaga, 1996). Terapi gen untuk pengobatan kanker di dasarkan pada koreksi percepatan pertumbuhan yang merupakan suatu pendekatan untuk mengontrol kecepatan tumbuh sel-sel kanker yaitu dengan melibatkan penggunaan oligonukleotida antisense (Milligan, 1994).

Sejumlah gen yang juga digunakan untuk terapi gen kanker adalah gen-gen yang berperan untuk menekan pertumbuhan tumor. Gen-gen penekan tumor berfungsi mendesak sel untuk bunuh diri bila sel-sel telah berubah sifat menjadi kanker. Gen-gen ini mengalami kerusakan pada berbagai tipe kanker sehingga para ilmuwan berupaya mengganti gen-gen yang rusak tersebut dengan gen-gen yang sehat (Mujoo, 1996; Ming, 1996). Upaya untuk membuat sistem imun membunuh sel kanker sangat bergantung pada sejumlah sitokin yang memiliki aktivitas melawan kanker ketika di suntikkan ke dalam tubuh atau langsung ke lokasi kanker, efek dari sejumlah sitokin tersebut menyebabkan sel-sel kanker sangat sensitive terhadap obat sehingga hanya akan membunuh sel yang mengandung gen tersebut (Osborne, 2004; Yoshida, 2004).

Dalam siklus hidup, virus memiliki periode ekstraseluler yang relatif singkat, sebelum menginfeksi sel, dan periode intraseluler yang lebih lama selama replikasi. Pada kebanyakan infeksi virus, sistem kekebalan memiliki mekanisme yang dapat menyerang virus pada kedua fase siklus hidupnya ini. Selama produksi protein atau fase perakitan virus, antigen yang muncul di membran sel yang terinfeksi dapat mengaktifkan respons imun yang menargetkan sel yang terinfeksi. Mekanisme kekebalan bawaan (non-spesifik) dan adaptif (spesifik) yang berbeda digunakan untuk melawan infeksi virus (Korobeinikov A, 2004; Osborne C, 2004).

Pada artikel ini akan dikembangkan suatu model dinamika interaksi antara sel inang virus yang meliputi sel kanker yang tidak terinfeksi, sel virus bebas dan selanjutnya menambahkan terapi gen untuk menghambat pertumbuhan sel kanker. Dinamika perubahan sel-sel tersebut dinyatakan dalam bentuk sistem persamaan differensial autonomous. Untuk mengetahui perilaku perubahan sel-sel tersebut, titik keseimbangan penyakit dan bebas penyakit dianalisis melalui pendekatan kestabilan secara lokal. Untuk itu, dalam analisis digunakan metode pelinearan di sekitar titik kesetimbangan model dan selanjutnya menganalisis nilai eigen dari matriks Jacobian yang berhasil untuk menentukan apakah terjadi penyebaran atau penyakit yang diderita pasien akan sembuh atau tidak. Lebih jauh, simulasi numerik diberikan untuk melihat visualisasi perubahan jumlah sel untuk masing-masing kompartemen. 


\section{B. Model Matematika Terapi Gen}

Model dasar matematis umum yang di gunakan untuk dinamika interaksi sel inang virus kemudian dikembangkan. Prinsip dasar yang mendasari model dinamis dari tindak lanjut infeksi virus. Sel tumor yang tidak terinfeksi, $X(t)$, terinfeksi ketika mereka bertemu virus bebas, $V(t)$. Sel kanker yang terinfeksi, $Y(t)$, menghasilkan partikel virus baru yang meninggalkan sel dan mencari sel kanker lain. Akibat infeksi yang berulang-ulang dalam pertumbuhan populasi virus. Pertumbuhan dibatasi oleh ketersediaan sel target (Korobeinikov, 2004). Mekanisme interaksi antar sel diberikan pada Gambar 1 sebagai berikut:

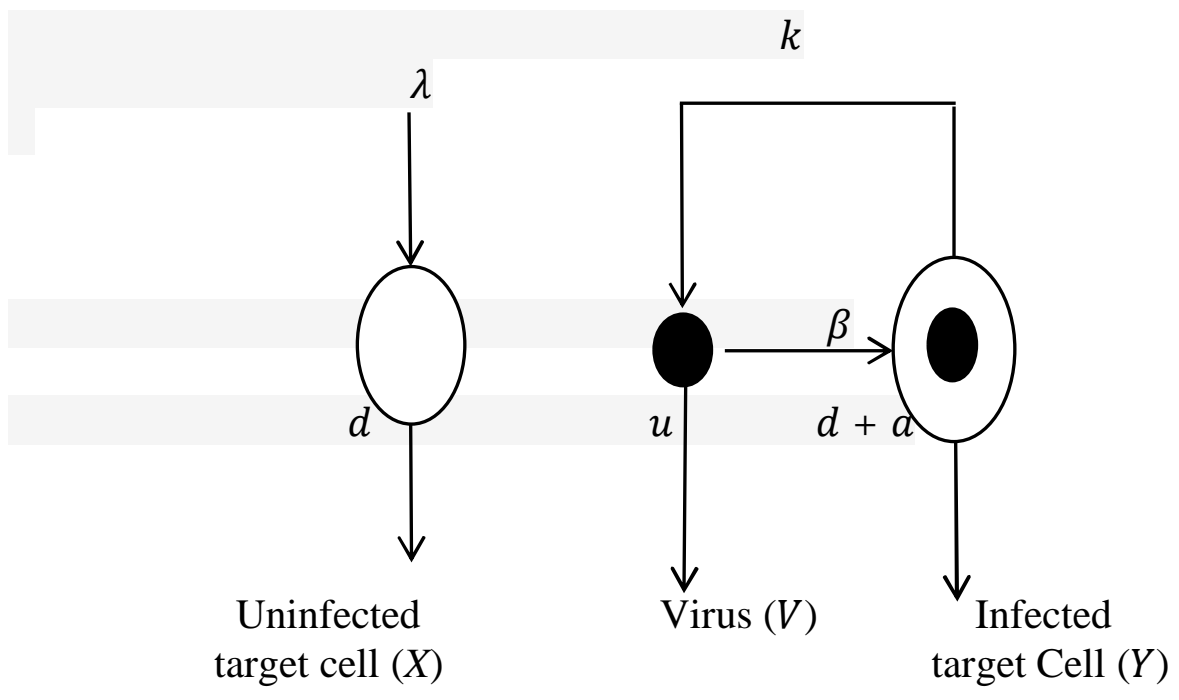

Gambar 1. Skema infeksi virus terhadap sel rentan.

Gambar 1. menyatakan skema bagaimana mekanisme yang terjadi pada sel tumor yang tidak terinfeksi, ketika sel tumor bertemu degan virus bebas dan bagaimana sel virus baru meninggalkan sel dan mencari sel kanker. Laju perubahan ketiga kompartemen sel pada Gambar 1. dinyatakan dalam bentuk sistem persamaan differensial seperti berikut.

$$
\begin{aligned}
& \frac{d X}{d t}=\lambda-a X-\beta X V, \\
& \frac{d Y}{d t}=\beta X V-(v+a) Y \\
& \frac{d Y}{d t}=\beta X V-(v+a) Y .
\end{aligned}
$$

Sel target yang tidak terinfeksi diproduksi dengan kecepatan konstan ' $\lambda$ ' dari kumpulan sel prekursor dan mati pada tingkat $\alpha x$. Ketika sel-sel yang rentan ini menemukan partikel virus bebas, mereka menjadi terinfeksi pada tingkat $\beta x v$. Sel yang terinfeksi mati dengan laju $v y$, yang disebabkan oleh infeksi virus (sitokpati atau sitoksisitas). Sel yang terinfeksi menghasilkan partikel virus baru dengan laju $f y$, dan partikel virus dilepaskan dari sel-sel tersebut. Jadi rata-rata umur sel yang terinfeksi adalah $1 /(\alpha+v)$; umur rata-rata partikel virus bebas adalah $1 / u$; jumlah partikel virus yang dihasilkan dari satu sel yang terinfeksi adalah $g /(\alpha+v)$

Selanjutnya pada model yang ditunjukan pada persamaan (1) dapat dikembangan dengan berbagai tujuan perspektif tertentu. Model terapi gen dikembangkan dari model LotkaVolterra dan model Kirschner dan Panneta di mana molekul efektor digantikan oleh 
pengembangbiakan sel sendiri (self proliferation) pada sel imun efektor. Kondisi bebas penyakit untuk model terapi gen adalah kondisi titik ekuilibrium bebas tumor, $T=0$. Selanjutnya akan dianalisa kestabilan titik ekuilibrium. Terapi gen dengan menggunakan virus Onyx P15 yang kemudian telah dimodifikasi ialah dengan menginduksi virus tersebut ke dalam sel kanker yang memiliki fungsi P53 abnormal. Sehingga hanya akan tumbuh dalam sel-sel tumor dengan fungsi P53 abnormal. Virus Onyx P15 menyebabkan kematian sel-sel kanker yang terserang virus dan tampaknya tidak mempengaruhi sel-sel normal dengan fungsi P53 yang normal (Lestari, 2015). Uji klinis fase III dengan Onyx P15 juga sedang berjalan dengan membandingkan pendekatan ini dengan terapi standar pada penderita tumor kepala dan leher. Berdasarkan asumsi di atas maka model terapi gen dengan menggunakan Onyx P53 dikembangkan dengan menambahkan satu kompartemen baru sebagai berikut.

$$
\begin{aligned}
& \frac{d T}{d t}=r T\left(1-\frac{T}{K}\right)-\beta T V-a T \\
& \frac{d Q}{d t}=\beta T V-\left(\frac{v}{1+p \cdot C}+a\right) \\
& \frac{d V}{d t}=\frac{f}{1+p \cdot C} \cdot Q-\mu V+b \\
& \frac{d C}{d t}=\frac{g \cdot Q \cdot C}{1+p \cdot C}-h \cdot C
\end{aligned}
$$

Keterangan untuk variabel dan parameter yang digunakan dalam model Terapi Gen ONYX P53 antara lain $T(t)$ (jumlah sel kanker), $V(t)$ (jumlah pertumbuhan virus), $C(t)$ (immunitas terhadap virus), $\alpha$ (laju kematian alami dari sel yang belum terinfeksi), $\beta$ (laju virus menginfeksi sel kanker), $e$ (half Saturation penghambat pertumbuhan virus), $f$ (laju pertumbuhan virus), $g$ (laju penambahan sel imun), $h$ (sel imun yang telah digunakan), $u$ (laju kematian alami virus), $R$ (laju proliferasi sel kanker), $K$ (kapasitas maksimum dari proliferasi sel kanker), $p$ (kapasitas maksimum dari sel imun) dengan masing-masing nilai dasarnya $10^{-3}\left(\frac{1}{\text { time }}\right), \quad 1\left(\frac{1}{\text { cell }}\right), 10^{-3}\left(\frac{1}{\text { time }}\right), 0.03\left(\frac{1}{\text { time }}\right), \quad 0.05\left(\frac{1}{\text { time }}\right), 10^{-3}\left(\frac{1}{\text { time }}\right), 10^{-3}\left(\frac{1}{\text { time }}\right)$, $10^{-3}\left(\frac{1}{\text { time }}\right), 0.18\left(\frac{1}{\text { time }}\right), 10^{-9}\left(\frac{1}{\text { cell }}\right), 10^{5}\left(\frac{1}{\text { cell }}\right)$. Sementara rentang nilai untuk parameter yang telah dinyatakan $\mathrm{di}$ atas secara berturut- turut diberikan seperti berikut, $\left(10^{-5}, 1\right),\left(10^{-5}, 10^{2}\right),\left(10^{-5}, 1\right),\left(0,10^{2}\right),\left(10^{-3}, 1\right),\left(10^{-5}, 1\right),\left(10^{-5}, 1\right)$, $\left(10^{-1}, 2\right),\left(0,10^{9}\right),\left(0,10^{5}\right)$.

\section{Metodologi Penelitian}

Identifikasi masalah dilakukan untuk menetapkan fokus permasalahan yang berkaitan dengan model matematika pada model pertumbuhan sel kanker dengan terapi gen. Studi literatur dilakukan terhadap jurnal penelitian yang telah dilakukan dan sumber pendukung lainnya untuk mempelajari hal-hal yang berkaitan dengan model matematika pada model pertumbuhan sel kanker dengan terapi gen dengan menggunakan ONYX Virus p53.

Setelah dilakukan studi literature, kemudian dilanjutkan dengan penyusunan masalah dan mengkonstruksi model matematika pada model pertumbuhan sel kanker dengan terapi gen ONYX Virus P53. Kemudian Untuk menganalisis kestabilan dari model yang dibuat, terlebih dahulu ditetapkan titik kesetimbangan (disease free equilibrium) dan penyakit (disease equilibrium). Model terapi gen menggunakan ONYX P53 yang dinyatakan dalam bentuk sistem persamaan differensial autonomous diberikan pada model (3) berikut. 


$$
\begin{aligned}
& \frac{d T}{d t}=r T\left(1-\frac{T}{K}\right)-\beta T V-a T \\
& \frac{d Q}{d t}=\beta T V-\left(\frac{v}{1+p \cdot C}+a\right) Q \\
& \frac{d V}{d t}=\frac{f}{1+p \cdot C} \cdot Q-\mu V+b \\
& \frac{d C}{d t}=\frac{g \cdot Q \cdot C}{1+p \cdot C}-h \cdot C .
\end{aligned}
$$

Simbol pada persamaan (3), $\frac{d T}{d t}$ menyatakan laju pertumbuhan sel kanker, $\frac{d Q}{d t}$ menyatakan laju sel terinfeksi, $\frac{d V}{d t}$ menyatakan laju pertumbuhan virus, $\frac{d C}{d t}$ menyatakan laju sel imun. Berdasarkan model (3), jumlah populasi (sel) dinyatakan sebagai

$$
N(t)=T(t)+Q(t)+V(t)+C(t) .
$$

Dengan asumsi persamaan (4), meskipun model (3) tidak memuat bentuk total populasi (sel), $N(\mathrm{t})$, tetapi secara tersirat dinamika untuk total populasi (sel) sudah terlibat dalam model (3). Dimanika total populasi bergantung kepada dinamika populasi (sel) yang lainnya.

\section{Hasil Penelitian dan Pembahasan}

Model dimanika perubahan sel yang diberikan pada model (3) akan ditentukan syarat kewujudan titik kesetimbangan penyakit dan titik kesetimbangan bebas penyakit. Selanjutnya titik kesetimbangan tersebut dianalis syarat-syarat yang mungkin dipenuhi untuk stabil atau tidak stabil secara lokal. Analisis kestabilan lokal dilakukan mengingat analisis kestabilan global cukup rumit untuk dilakukan mengingat modelnya cukup kompleks. Dalam kasus analisis kestabilan global sangat sulit dilakukan, maka biasanya dilakukan metode yang standard dan peneliti gunakan dalam menganalisis perilaku sistem secara lokal saja. Untuk itu, dilakukan pelinearan di sekitar titik kesetimbangan model yang menjadi fokus kajian.

Teorema berikut digunakan untuk menganalisis kestabilan lokal dari titik keseitimbangan dari sistem (3)

Teorema 1 (Olsder dkk, 2004):

Diberikan sistem persamaan diferensial linear $\dot{X}=A x$, dengan titik kesetimbangan $\bar{x}$ yang terisolir, $A$ adalah matriks berukuran $n x n$, mempunyai $k$ nilai eigen yang berbeda $\lambda_{1}, \lambda_{2}, \lambda_{3}$, $\ldots, \lambda_{k}$ dan $k \leq n$, maka

1. Titik kesetimbangan $\bar{x}=0$, stabil secara asimtotik jika dan hanya jika $\mathfrak{R}\left(\lambda_{i}\right)<$ $0, \forall_{i}=1,2,3, \ldots, k$.

2. Titik kesetimbangan $\bar{x}=0$, stabil jika dan hanya jika $\mathfrak{R}\left(\lambda_{i}\right)<0, \forall_{i}=1,2,3, \ldots, k$. dan jika setiap nilai eigen $\lambda_{i}$ imajiner dengan $\mathfrak{R} e\left(\lambda_{i}\right)=0$, dan multiplisitas aljabar dan geometri untuk nilai eigennya sama.

3. Titik kesetimbangan $\bar{x}=0$, tidak stabil jika dan hanya jika terdapat $\mathfrak{R} e\left(\lambda_{i}\right)>$ 0 , untuk suatu $i=1,2,3, \ldots, k$, atau jika ada $\lambda_{i}$ imajiner dengan $\Re e(\lambda i)=0$, dan multiplisitas aljabar lebih dan multiplisitas geometri untuk nilai eigen tidak sama.

Berdasarkan Teorema 1, Titik kesetimbangan $\bar{x}$ dikatakan stabil asimtotik jika dan hanya jika $\mathfrak{R}\left(\lambda_{i}\right)<0, \forall_{i}=1,2,3, \ldots, k$. Titik kesetimbangan model pada persamaan (3) dianlisis dengan melinearkan model di sekitar titik kestimbangan, dan dengan demikian diperoleh matriks Jacobi sebagai berikut 


$$
J=\left[\begin{array}{cccc}
r-\frac{2 . r . T}{K} \beta V-a-\lambda & 0 & -\beta T & 0 \\
\beta V & -\left(\frac{v}{1+p \cdot C}+a\right)-\lambda & \beta T & \frac{p v}{(1+p \cdot C)^{2}} \\
0 & \frac{f}{1+p \cdot C} & -\mu-\lambda & -\frac{f v}{(1+p \cdot C)^{2}} \\
0 & \frac{g \cdot C}{1+p \cdot C} & 0 & \frac{g \cdot Q}{(1+p \cdot C)^{2}}-h-\lambda
\end{array}\right]
$$

Titik-titik kesetimbangan bebas penyakit dan penyakit dari sistem (3) tercapai ketika semua laju kompartemen ditetapkan menjadi $0, \frac{d C}{d t}=0, \frac{d Q}{d t}=0, \frac{d T}{d t}=0, \frac{d V}{d t}=0$. Dengan demikian diperoleh

$$
\begin{aligned}
r T\left(1-\frac{T}{K}\right)-\beta T V-a T & =0 \\
\beta T V-\left(\frac{v}{1+p . C}+a\right) Q & =0 \\
\frac{f}{1+p . C} Q-\mu V+b & =0 \\
\frac{g Q C}{1+p C}-h C & =0
\end{aligned}
$$

Dengan menyelesaikan sistim persamaan (6), diperoleh lima titik kesetimbangan untuk model (3) yaitu $Q_{1}, Q_{2}, Q_{3}, Q_{4}, Q_{5}$ dengan $Q_{k}=\left(C_{k}, Q_{k}, T_{k}, V_{k}\right)$ yaitu

$$
\begin{aligned}
& Q_{1}=\left(0,0,0, \frac{b}{\mu}\right), \\
& Q_{2}=\left(\frac{\left(\mu \sqrt{K \beta^{2} f Z^{2}+(K \alpha \beta f-K \beta f r+\alpha \mu r+\mu r v)_{-} Z-\alpha b r-b v r}\right)-b}{f},\right. \\
& \frac{\left(\left(\beta \sqrt{K \beta^{2} f Z^{2}+(K \alpha \beta f-K \beta f r+\alpha \mu r+\mu r v)_{-} Z-\alpha b r-b v r}\right)+\alpha-\mathrm{r}\right) K}{r}, \\
& \frac{\left(\left(-\beta \sqrt{K \beta^{2} f Z^{2}+(K \alpha \beta f-K \beta f r+\alpha \mu r+\mu r v) \_Z-\alpha b r-b v r}\right)+\alpha-r\right) K}{f}, \\
& \left.\left(\left(\sqrt{K \beta^{2} f Z_{-}^{2}+(K \alpha \beta f-K \beta f r+\alpha \mu r+\mu r v)_{-} Z-\alpha b r-b v r}\right)\right)\right), \\
& Q_{3}=\left(\left(-\frac{\alpha+v}{\alpha p}\right),\left(-\frac{h v}{\alpha g}\right), 0,\left(\frac{b g+h f}{g \mu}\right)\right), \\
& Q_{4}=\left(\frac{\left(\left(-K \alpha b \beta g 2 \mu+K \alpha \beta f g h \mu+K b^{2} \beta^{2} g^{2}+2 K b \beta^{2} f g h-K b \beta g^{2} \mu r+K \beta^{2} f^{2} h^{2}-K \beta f g h \mu r+\alpha h \mu^{2} g r+h \mu^{2} v g r\right)\right)}{g \mu^{2} r a h p},\right. \\
& \frac{\left(\left(-K \alpha b \beta g 2 \mu+K \alpha \beta f g h \mu+K b^{2} \beta^{2} g^{2}+2 K b \beta^{2} f g h-K b \beta g^{2} \mu r+K \beta^{2} f^{2} h^{2}-K \beta f g h \mu r+h \mu^{2} v g r\right)\right)}{g^{2} \mu^{2} r \alpha} \\
& \left.\frac{((-K(\alpha g \mu+b \beta g+\beta f h-g \mu r))}{g \mu r}, \frac{((b g+h f))}{g \mu}\right), \\
& Q_{5}=\left(0, \frac{1}{f}\left(\frac { 1 } { 2 K \beta ^ { 2 } f } \left(\left(K \alpha \beta f-K \beta f r+\alpha \mu r+\mu r v-\left(K^{2} \alpha^{2} \beta^{2} f^{2}-2 K^{2} \alpha \beta^{2} f^{2} r+\right.\right.\right.\right.\right. \\
& K^{2} \beta^{2} f^{2} K^{2} \alpha^{2} \beta^{2} r^{2}+2 K^{2} \alpha \beta f \mu r+4 K \alpha^{2} b \beta^{2} f r-2 K \alpha \beta f \mu r^{2}+2 K \alpha \beta f \mu r v+ \\
& \left.\left.\left.\left.4 K b \beta^{2} f r v-2 K \beta f \mu r^{2} v+\alpha^{2} \mu^{2} r^{2}+2 \alpha \mu^{2} r^{2} v\right)^{1 / 2}\right) \mu\right)-b\right), \quad \frac{1}{f}\left(\frac{1}{2 K \beta^{2} f}((K \alpha \beta f-K \beta f r+\right.
\end{aligned}
$$




$$
\begin{aligned}
& \alpha \mu r+\mu r v-\left(K^{2} \alpha^{2} \beta^{2} f^{2}-2 K^{2} \alpha \beta^{2} f^{2} r+K^{2} \beta^{2} f^{2} K^{2} \alpha^{2} \beta^{2} r^{2}+2 K^{2} \alpha \beta f \mu r+\right. \\
& 4 K \alpha^{2} b \beta^{2} f r-2 K \alpha \beta f \mu r^{2}+2 K \alpha \beta f \mu r v+4 K b \beta^{2} f r v-2 K \beta f \mu r^{2} v+\alpha^{2} \mu^{2} r^{2}+ \\
& \left.\left.\left.2 \alpha \mu^{2} r^{2} v\right)^{1 / 2}+\alpha-r\right) K\right), \quad \frac{1}{f}\left(\frac { 1 } { 2 K \beta ^ { 2 } f } \left(\left(K \alpha \beta f-K \beta f r+\alpha \mu r+\mu r v-\left(K^{2} \alpha^{2} \beta^{2} f^{2}-\right.\right.\right.\right. \\
& 2 K^{2} \alpha \beta^{2} f^{2} r+K^{2} \beta^{2} f^{2} K^{2} \alpha^{2} \beta^{2} r^{2}+2 K^{2} \alpha \beta f \mu r+4 K \alpha^{2} b \beta^{2} f r-2 K \alpha \beta f \mu r^{2}+ \\
& \left.\left.\left.2 K \alpha \beta f \mu r v+4 K b \beta^{2} f r v-2 K \beta f \mu r^{2} v+\alpha^{2} \mu^{2} r^{2}+2 \alpha \mu^{2} r^{2} v\right) 1 / 2\right)\right) .
\end{aligned}
$$

Dari kelima titik kesetimbangan yang diperoleh, boleh jadi tidak semua titik kesetimbangan akan dipertimbangakan. Hanya titik kesetimbangan dengan komponen tidak negatif yang bermakna dan akan dianalisis.

\section{Simulasi Numerik}

Hasil numerik solusi sistem (3) merupakan gambaran hasil analisis pada bagian sebelumya. Simulasi numerik dilakukan dengan menggunakan nilai parameter dasar dan nilai parameter pembanding untuk melihat bagaimana efektivitas terapi gen ONYX-P53. Adapun Parameter-parameter yang digunakan yaitu $[\alpha, \beta, f, g, h, u, r, K, p, b, v]$, masing-masing dengan nilai parameter dasar dan parameter pembanding yaitu $\left[10^{-3}, 0.2,0.08,0.01,0.01\right.$, $\left.0.01,0.18,10^{8}, 10^{3}, 0.01,0.06\right],\left[10^{-3}, 0.01,0.12,0.01,0.01,0.01,0.18,10^{8}, 10^{3}\right.$, $0.012,0.06]$.

Pada parameter dasar menghasilkan lima titik kesetimbangan yaitu $Q_{1}, Q_{2}, Q_{3}, Q_{4}$ dan $Q_{5}$ sebagai berikut $Q_{1}=(0,0,0,1), Q_{2}=\left(0,-0.125,9.94 \times 10^{7}, \quad-3.83 \times 10^{-10}\right), Q_{3}=$ $(0,-0.013,-0.0045,0.895), \quad Q_{4}=(-0.061,-60,0,9), \quad Q_{5}=\left(-1.62 \times 10^{9},-\right.$ $\left.1.62 \times 10^{12},-9.006,9\right)$. Sedangkan pada parameter pembanding juga menghasilkan lima titik kesetimbangan yaitu $Q_{1}, Q_{2}, Q_{3}, Q_{4}$ dan $Q_{5}$ sebagai berikut $Q_{1}=(0,0,0,1.2), Q_{2}=$ $(0.47,1.39,17.48,0), \quad Q_{3}=(9.94,-0.100000005,-6.134,0), \quad Q_{4}=(0,-60,13.2 \times$ $\left.10^{6},-0.06\right), Q_{5}=\left(2.61 \times 0^{7}, 3.45 \times 10^{9}, 13.2,2.61\right)$. Titik kesetimbangan dikatakan ada jika tidak terdapat nilai $C_{k}, Q_{k}, T_{k}, V_{k}<0$, maka pada parameter dasar titik $Q_{1}, Q_{2}, Q_{3}$ dan $Q_{4}$ tidak ada. Sedangkan pada parameter pembanding titik $Q_{3}$ dan $Q_{4}$ tidak ada.

Pada simulasi yang diberikan, diperlihatkan bagaimana kewujudan dan kestabilan titik kesetimbangan dengan penyakit dan titik keseimbangan bebas penyakit. Selain itu diberikan nilai eigen yang bersesuaian dengan titik kesetimbangan untuk menentukan kestabilan titik keseimbangan tersebut yang diperoleh dari matriks Jacobian.

\section{a. Simulasi Untuk Titik Kesetimbangan Penyakit}

Titik kesetimbangan penyakit merupakan keadaan saat ketidakmampuan virus dalam menekan laju pertumbuhan sel kanker. Pada parameter dasar tidak memiliki titik kesetimbangan penyakit sedangkan pada parameter pembanding titik kesetimbangan penyakit yaitu $Q_{2}=(0.47,1.39,17.48,0) \quad$ dan $\quad Q_{5}=\left(2.61 \times 0^{7}, 3.45 \times 10^{9}, 13.2,2.61\right)$. Pada parameter dasar, terdapat satu titik kesetimbangan bebas penyakit yaitu $Q_{1}$. Titik $Q_{1}$ menghasilkan 3 nilai eigen yaitu $\lambda_{1}=-0.021$ dan $\lambda_{2}=-0.061$ dan $\lambda_{3}=-0.01$.

Berdasarkan Teorema 1. titik kesetimbangan $Q_{1}$ stabil. Pada parameter pembanding, terdapat satu titik kesetimbangan bebas penyakit yaitu $Q_{1}$. Titik kesetimbangan $Q_{1}$ menghasilkan nilai eigen yaitu $\lambda_{1}=0.167, \lambda_{2}=-0.061, \lambda_{3}=-0.01, \lambda_{4}=-0.01$ Karena terdapat $\lambda_{1}=0.167>0$ maka titik kesetimbangan $Q_{1}$ pada parameter pembanding tidak stabil. Berikut ini diberikan ilustrasi hasil analisis model, yang menggambarkan perubahan masing-masing sel yang terlibat dalam model, Gambar 2. 

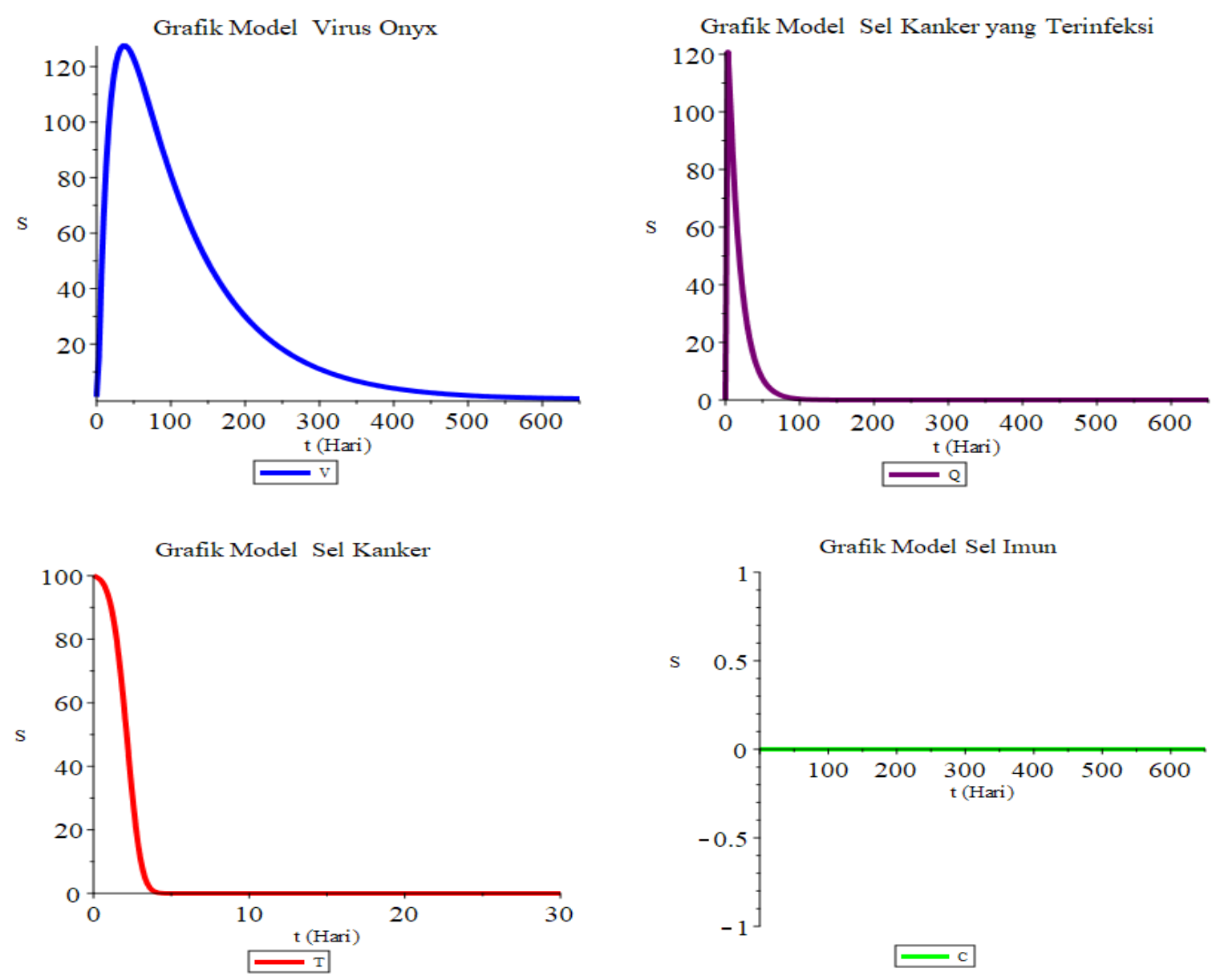

Gambar 2. Grafik Model Kompetisi Virus Onyx dan Sel Kanker di sekitar titik $Q_{1}$.

Gambar 2. menunjukkan ketika tidak terdapat interaksi sel imun selama proses terapi, sel kanker bebas atau sel kanker yang tidak terinfeksi habis kurang dari 10 hari, sel kanker yang terinfeksi habis dalam kurun waktu kurang 100 hari, dan virus ONYX P-53 habis dalam waktu sekitar 600 hari.

\section{b. $\quad$ Simulasi Untuk Titik kesetimbangan Bebas Penyakit}

Titik kesetimbangan bebas penyakit merupakan keadaan saat sel kanker berkurang atau habis. Titik kesetimbangan bebas penyakit pada parameter dasar dan pembanding masingmasing $Q_{1}=(0,0,0,1.2)$ dan $Q_{1}=(0,0,0,1.2)$. Pada parameter dasar, tidak terdapat titik kesetimbangan bebas penyakit. Sedangkan pada parameter pembanding terdapat dua titik kesetimbangan penyakit yaitu $Q_{2}$ dan $Q_{5}$. Titik kesetimbangan $Q_{2}$ menghasilkan empat nilai eigen yaitu $\lambda_{1}=-0.085$ dan $\lambda_{2}=0.004, \lambda_{3}=0.007+0.04 \mathrm{i}$ dan $\lambda_{4}=0.007-0.04 \mathrm{i}$. Titik kesetimbangan $Q_{2}$ tidak stabil karena $\lambda_{1,2}>0$ dan $\mathfrak{R} e\left(\lambda_{3,4}\right)>0$. Titik $Q_{5}$ menghasilkan 4 nilai eigen yaitu $\lambda_{1}=-0.048$ dan $\lambda_{2}=-0.01, \lambda_{3}=-0.006$ dan $\lambda_{4}=-0.006$. Titik kesetimbangan $Q_{5}$ stabil karena semjua nilai bernilai negatif, yaitu $\lambda_{1,2,3,4}<0$. Perilaku jumlah sel pada model di sekitar titik kesetimbangan bebas penyakit diberikan pada Gambar 3 . 

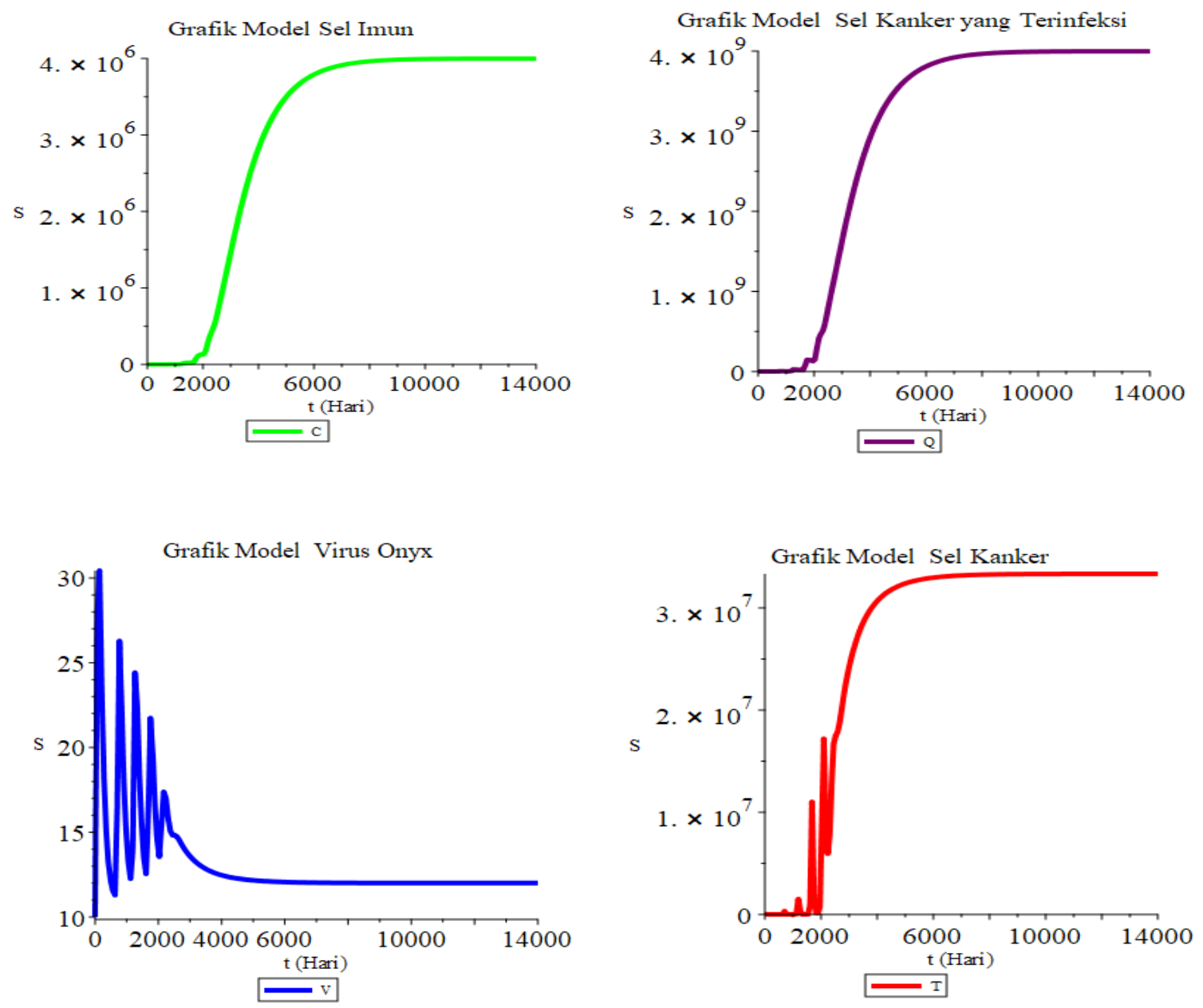

Gambar 3. Grafik model kompetisi virus ONYX dan Sel Kanker di sekitar titik $Q_{5}$.

Gambar 3. menunjukkan terdapat adanya interaksi sel imun selama proses terapi. Dengan semakin banyaknya sel imun yang diproduksi, jumlah sel kanker bebas dan sel kanker terinfeksi semakin banyak. Namun jumlah virus ONYX P-53 semakin menurun dan stabil pada titik equilibrium $Q_{5}\left(V_{5}\right)$ yaitu 2.61 .

Berdasarkan dua simulasi tersebut yaitu pada gambar 2 dan 3 menunjukkan pengaruh interaksi sel imun selama proses terapi sel kanker menggunakan virus ONYX-P53. Dengan tidak terdapat nya interaksi sel imun dengan virus, sehingga dapat dikatakan pengobatan sel kanker akan berhasil dengan jangka waktu yang cukup singkat. Kemudian proses pembersihan virus dari dalam tubuh memakan waku kurang dari 2 tahun. Namun ini masih tergantung dari nilai awal atau kondisi pasien sebelum proses terapi. Sebaliknya jika terdapat pengaruh sel imun selama proses terapi, maka pengobatan dapat dikatan gagal karena sel imun berinteraksi dengan virus yang berpotensi menghambat proses terapi. Akibatnya pertumbuhan laju sel kanker lebih cepat ketimbang laju pertumbuhan virus ONYX-P53.

\section{E. Kesimpulan}

Berdasarkan analisis dan simulasi yang dilakukan dapat disimpulkan bahwa model matematika tentang pengaruh terapi gen terhadap dinamika pertumbuhan sel kanker, virus dan sel imun yang menghasilkan suatu sistem persamaan diferensial non linear yang diberikan pada model (3) diperoleh satu titik kesrtimbangan bebas penyakit yaitu $Q_{1}$ dan satu titik 
kesetimbangan penyakit $Q_{5}=\left(2.61 \times 0^{7}, 3.45 \times 10^{9}, 13.2,2.61\right)$. Berdasarkan simulasi (1) dan (2) dan dengan memberikan nilai-nilai parameter yang sesuai dan nilai terapi gen yang sesuai maka titik kesetimbangan bebas penyakit memenuhi syarat kestabilan suatu titik dalam sistem persamaan differensial. Sehingga dari kajian secara model matematika dapat disimpulkan bahwa dengan memberikan kadar terapi gen yang sesuai, yaitu dengan menggunakan virus ONYX P53 untuk mengobati sel kanker dapat dilakukan jika tidak terdapat interaksi sel imun dalam proses terapi dan pasien penderita dapat sembut dari penyakitnya.

\section{DAFTAR PUSTAKA}

Arteaga CL, Holt JT.(1996). Tissue-targeted antisense c-fos retroviral vector inhibits established breast cancer xenografts in nude mice. Cancer Res.;56(5):1098-1103. Retrieved fromhttps://pubmed.ncbi.nlm.nih.gov/8640767/

Anderson, W. F.(2000). Gene therapy scores against cancer. Nat Med 6, 862-863. https://doi.org/10.1038/78610

Carter, J.B., \& Saunders, V.A. (2007). Virology: principles and applications. Hoboken, NJ, John Wiley \& Sons.

Osborne C, Wilson P, Tripathy D. (2004). Oncogenes and tumor suppressor genes in breast cancer: potential diagnostic and therapeutic applications. Oncologist. 9(4):361-77. doi: 10.1634/theoncologist.9-4-361.

Korobeinikov A. (2004). Global properties of basic virus dynamics models: Bull Math Biol. 66(4):879-83. doi: 10.1016/j.bulm.2004.02.001.

Milligan, J.F., Jomes, R.J.,\& Froehler, B.C. (1994). Development of Antisense Therapeutics: Annals of the New York Academy of Sciences. 716:228-41. Retrieved From https://www.meta.org/papers/development-of-antisense-therapeutics/8024196

Ming, Yu. (1996). Advances in Cancer Gene Therapy: McGill Journal of Med. 2:93106.doi.org/10.26443/mjm.v2i2.702

Mujoo K, Maneval DC, Anderson SC, Gutterman JU. (1996). Adenoviral-mediated p53 tumor suppressor gene therapy of human ovarian carcinoma. Oncogene. 12(8):1617-23. Retrieved fromhttps://pubmed.ncbi.nlm.nih.gov/8622881/

Olsder, G. J\&Woude, J. W. van der. (2004). Mathematical Systems Theory. Netherland: VVSD.

Osborne C, Wilson P, Tripathy D. (2004). Oncogenes and tumor suppressor genes in breast cancer: potential diagnostic and therapeutic applications. Oncologist. 9(4):361-77. doi: 10.1634/theoncologist.9-4-361.

Wargasetia., Teresa. L. (2005). Terapi Gen Pada Penyakit Kanker: Maranatha Journal of Medicine and Health., vol. 4,no.2.

Lestari, D., Sari, E. R., \& Arifah, H. (2019). Dynamics of a mathematical model of cancer cells with chemotherapy: Journal of Physics. doi:10.1088/1742-6596/1320/1/012026 
Lai, Xiulan. (2014). Study of Virus Dynamics by Mathematical Models: Electronic Thesis and Dissertation Repository. 1978. Retrieved Fromhttps://ir.lib.uwo.ca/etd/1978

Lestari, D., \& Ambarwati, R. A. (2015). A Local Stability of Mathematical Models for Cancer Treatment by Using Gene Therapy: International Journal of Modeling and Optimization, 5(3). DOI: 10.7763/IJMO.2015.V5.462

Yoshida J, Mizuno M, Wakabayashi T. (2004).Interferon-beta gene therapy for cancer: basic research to clinical application. Cancer Sci. 95(11):858-65. doi: 10.1111/j.13497006.2004.tb02194.x.

Yoshida T, Ohnami S, Aoki K. (2004). Development of gene therapy to target pancreatic cancer. Cancer Sci. 95(4):283-9. doi: 10.1111/j.1349-7006.2004.tb03204.x. 